ISSN 1392-3196 / e-ISSN 2335-8947

Zemdirbyste-Agriculture, vol. 107, No. 1 (2020), p. 25-32

DOI 10.13080/z-a.2020.107.004

\title{
Changes in weed flora under the influence of long term application of liming and reduced soil tillage
}

\author{
Regina SKUODIENE $\dot{1}^{1}$, Danute KARČAUSKIENE ${ }^{1}$, Virginijus FEIZA², Dalia FEIZIENE ${ }^{2}$, \\ Regina REPŠIENE ${ }^{1}$, Gintaras ŠIAUDINIS ${ }^{1}$ \\ ${ }^{1}$ Lithuanian Research Centre for Agriculture and Forestry, Vëžaičiai Branch \\ Gargždų 29, Vèžaičiai, Klaipėda distr., Lithuania \\ E-mail: regina.skuodiene@lammc.lt \\ ${ }^{2}$ Lithuanian Research Centre for Agriculture and Forestry, Institute of Agriculture \\ Instituto 1, Akademija, Kèdainiai distr., Lithuania
}

\begin{abstract}
Many soil improvement practices are directly related to the reduction of weed infestation in crops. Sustainable use of the acid moraine loam Bathygleyic Distric Glossic Retisol prevailing in Western Lithuania is associated with the appropriate intensity of liming and tillage. Research was carried out at the Vèžaičiai Branch of Lithuanian Research Centre for Agriculture and Forestry during the period 2015-2018 in two long-term field experiments: liming (established in 1949) and soil tillage methods (established in 2003). The aim of the study was to establish the trends in weed infestation variation in the crop rotation after a long-term application of agronomic practices of different intensity (soil tillage and liming). Treatments of the soil tillage were as follows: conventional ploughing, shallow ploughing and shallow ploughless tillage. Treatments of liming were as follows: unlimed $\left(\mathrm{pH}_{\mathrm{KCl}} 4.0-4.1\right)$ and limed $\left(\mathrm{pH}_{\mathrm{KCl}}\right.$ 6.2-6.8). The following weed infestation indicators were investigated: weed number and mass, weed species number, weed seed bank in the soil depths of 0-10, 10-20 and 20-30 cm.

Findings of the study suggest that the long-term liming had an impact on the disappearance of dominating acidophilic weeds from crop communities. In a limed soil ( $\mathrm{pH}$ 6.4-6.8), the total number of weeds was 4.1 times lower compared to that in a naturally acid soil ( $\mathrm{pH} 4.0-4.1)$. The contamination with weed seeds was 14.2 times greater in the naturally acid soil; however, irrespective of the soil acidity $(\mathrm{pH})$, vertical seed distribution was determined to be similar in different depths of the soil. The long-term conventional ploughing reduced crop weediness in the soil of low acidity (5.1-5.3). The total weed number and mass were 1.6 and 1.4 times greater in the treatment of reduced tillage soil. The effect of long-term regular soil tillage tended to cause changes to the depth of soil loosening, affecting vertical weed seed distribution. Under reduced tillage conditions, the soil depth of 0-10 $\mathrm{cm}$ was the most contaminated with weed seeds.
\end{abstract}

Key words: acid soil, liming, primary soil tillage, seed bank, weed number and dry biomass.

\section{Introduction}

Weeds are a permanent component of agroecosystems and remain the most important factor causing yield reduction (Auškalnienè et al., 2011). Crop yield losses to weed competition have been estimated as 9\% globally (Oerke, 2006). Weed specific composition mostly depends on the anthropogenic activity (Fried et al., 2008). Weed flora is affected by the changes in crop rotation (Hosseini et al., 2014), use of herbicides (Andreasen, Streibig, 2011), fertilization and liming (Ciuberkis et al., 2006; Karcauskiene et al., 2016) and management strategies (Deveikyte et al., 2006; Seehusen et al., 2017). Crop rotation is one of the factors to prevent the spread of weeds. It was established that cereals may account for $50 \%$ of a crop rotation, but if it is possible to effectively control weeds and pests, cereals may occupy $67 \%$ or $100 \%$, when legumes are grown in a crop rotation (Auškalnienè et al., 2011).
European Community's agricultural policy has strongly encouraged conservation tillage practices, such as no-tillage and reduced tillage (European Union, 2000). Reduced tillage system involves, among others, a reduction in the number of tillage operations, shallower ploughing, replacing the plough by other implements, or the use of direct drilling. Low labour intensity of this system also makes it possible to grow crops in locations where it is a problem to maintain optimal sowing time (Gawęda et al., 2015). Although effects on cereal grain yield have not been consistent, conservation tillage can reduce soil erosion and improve soil fertility and soil water retention (Berner et al., 2008). Furthermore, desirable effects of conservation tillage may include the reduction of energy requirements for weed control, carbon sequestration and mitigation of greenhouse gas emissions (Meyer-Aurich et al., 2006), because

Please use the following format when citing the article:

Skuodienė R., Karčauskienė D., Feiza V., Feizienė D., Repšienė R., Šiaudinis G. 2020. Changes in weed flora under the influence of long term application of liming and reduced soil tillage. Zemdirbyste-Agriculture, 107 (1): 25-32. DOI 10.13080/z-a.2020.107.004 
consequences of this intensive agriculture are now well known with an important increase of atmospheric $\mathrm{CO}_{2}$ concentrations, water pollution and biodiversity loss (Gaba et al., 2014).

Guinjuan et al. (2016) indicate that no-tillage has resulted in difficulties in controlling certain weed species. Decreasing tillage intensity increased the amounts of weeds, particularly of meadow grass (Poa annua L.) (Seehusen et al., 2017). In no-tillage, in addition to the fact that seeds stay close to the soil surface, greater crop residue also remains on the soil surface, suppressing weed emergence due to a mulch effect or allelopathy (Khan et al., 2000). Therefore, a modification of the size of the seedbank will result in changes of the emerging weed populations and vice versa. Furthermore, it is possible that weed seeds migrate into the plots from the surroundings of the farm or from deeper soil layers during ploughing (Riemens et al., 2007). As reported by Woźniak (2007), from $60 \%$ to $90 \%$ of the seed bank may be deposited in the topsoil. During mechanical cultivation, weed seeds with a short resting period are transferred from the topsoil into deeper soil layers, from where only few are capable of sprouting. It results in a depletion of the seed bank in the soil and, thus, in lesser crop infestation with weeds (Riemens et al., 2007; Gruber, Claupein, 2009).

Agricultural plants and weeds differently react to soil acidity, which determines plant nutrition, distribution and productivity. Liming of acid soils changes their characteristics as well as plant growth conditions (Skuodienè, Repšienè, 2009). The research conducted on a Bathygleyic Distric Glossic Retisol showed that in the first year of organic fertilizer effect, i.e. in the stand of winter wheat, the weed number strongly correlated with soil agrochemical parameters tested: mobile aluminium (Al), hydrolytic acidity, calcium ( $\mathrm{Ca}$ ) and magnesium $(\mathrm{Mg})$ content and $\mathrm{pH}_{\mathrm{KCl}}$.

Weed flora has markedly changed in the crops of Lithuania during the last decades (Auškalniene et al., 2011). Bathygleyic Distric Glossic Retisols prevailing in Western Lithuania are acid, low in organic matter and contain high level of toxic $\mathrm{Al}^{3+}$ (Repsiene, Karcauskiene, 2016; Volungevicius et al., 2018).

Based on these observations, we hypothesised that reduced soil tillage would increase the weed number and soil contamination with weed seeds, while the acid soil liming would affect the weed number and soil contamination with weed seeds in the opposite way.

The aim of the study was to establish the trends in weed infestation variation in the crops of the rotation after a long-term application of agronomic practices of different intensity (soil tillage and liming).

\section{Materials and methods}

Experimental site. Research into the effects of the soil tillage methods and liming on crop weediness was carried out during the period 2015-2018 in two long-term field experiments carried out at Véžaičiai Branch of the Lithuanian Research Centre for Agriculture and Forestry in Klaipeda district. According to the content of clay particles, the soil profile is differentiated into alluvial and illuvial horizons whose diagnostic horizons: $\mathrm{A}(0-27 \mathrm{~cm})$ $-\mathrm{El}(27-55 \mathrm{~cm})-\mathrm{ElB}(55-80 \mathrm{~cm})-\mathrm{BtEl}(80-105 \mathrm{~cm})-$ BCg (105-120 cm) (Kryzevicius et al., 2019). The soil is typical of the region of Western Lithuania.

Two experiments were carried out to achieve the aim of the research.

Experiment I - long-term liming impact on agrophytocenosis. A field experiment was established in 1949. Geographical location of the site: lat. $55^{\circ} 69^{\prime} \mathrm{N}$, long. $21^{\circ} 49^{\prime}$ E. The soil was Bathyglevic Dystric Glossic Retisol (WRB, 2014) formed on medium-moraine loam with a texture of sandy loam (clay particles $<0.002 \mathrm{~mm}$ $-13-15 \%)$.

Liming treatments: 1) unlimed $\left(\mathrm{pH}_{\mathrm{KCl}} 4.0-4.1\right)$ and 2 ) limed at 2.0 rates every $3-4$ years $\left(\mathrm{pH}_{\mathrm{KCl}}^{\mathrm{KCl}} 6.2-6.8\right)$. The unlimed soil was moderate in humus status (humus $-2.43 \%$, organic carbon $\left.\left(\mathrm{C}_{\mathrm{org}}\right)-1.41 \%\right)$, high in mobile phosphorus $\left(\mathrm{P}_{2} \mathrm{O}_{5}\right)$ and potassium $\left(\mathrm{K}_{2} \mathrm{O}\right)$ content $(265$ and $294 \mathrm{mg} \mathrm{kg}^{-1}$ soil, respectively) and moderate in mobile aluminium ( $\mathrm{Al})$ content $\left(73.3 \mathrm{mg} \mathrm{kg}^{-1}\right)$ with $\mathrm{pH} 4.08$. The limed soil was moderate in humus status (humus $-2.17 \%$, $\mathrm{C}-1.26 \%$ ) and high in mobile $\mathrm{P}_{2} \mathrm{O}_{5}$ and $\mathrm{K}_{2} \mathrm{O}$ content (243 and $249 \mathrm{mg} \mathrm{kg}^{-1}$ soil, respectively) with pH 6.3. The soil was limed systematically: in 1949, the primary liming was done with slaked lime, in 1964, liming with slaked lime was repeated, and in the period of 1985-2005, the soil was limed periodically every $3-4$ years in a sevenfield rotation incorporating powder limestone at 2.0 rates $\left(15 \mathrm{t} \mathrm{ha}^{-1} \mathrm{CaCO}_{3}\right.$ ) chosen according to the soil hydrolytic acidity. Soil tillage was conventional ploughing.

The four-course crop rotation consisted of: in 2015 - spring rape (Brassica napus L. ssp. oleifera annua Metzg) cultivar 'Fenja', in 2016 - spring barley (Hordeum vulgare L.) cultivar 'Luoke' with undersown red clover (Trifolium pratense L.), in 2017 - red clover 'Liepsna' of the first year of use (2017), in 2018 - winter triticale $(\times$ Triticosecale Wittm.) cultivar 'Todant'. The crops were fertilised with mineral fertilisers. The rate for the spring rape was $\mathrm{N}_{120} \mathrm{P}_{90} \mathrm{~K}_{150}$, for the stand of barley with undersown perennial grasses $-\mathrm{N}_{60} \mathrm{P}_{60} \mathrm{~K}_{90}$, for the perennial grasses of the first year of use $-\mathrm{P}_{90}^{60} \mathrm{~K}_{00}$, for the winter triticale $-\mathrm{N}_{90} \mathrm{P}_{60} \mathrm{~K}_{100}$. Before sowing, the grains of winter triticale and spring barley were treated with Kinto (a.i. triticonazole + prochloraze) at a rate of $2 \mathrm{~L} \mathrm{t}^{-1}$. Plant protection products (pesticides) were used. In 2015 at BBCH 05, Butisan 400 a.i. (a.i. metazachlor) $2.5 \mathrm{~L} \mathrm{ha}^{-1}$, at BBCH 10 Fury (a.i. zeta-cypermethrin) $0.1 \mathrm{~L} \mathrm{ha}^{-1}$, at BBCH 51 Fury (a.i. zeta-cypermethrin) $0.1 \mathrm{~L} \mathrm{ha}^{-1}$. In 2016 at BBCH 13 Allegro Super (a.i. krezoksim-methil + epoxiconazol + fenpropimorph) $0.75 \mathrm{~L} \mathrm{ha}^{-1}$, at BBCH 41-43 Fastac 50 EC (a.i. alphacypermethrin) $0.25 \mathrm{~L} \mathrm{ha}^{-1}+$ Allegro Super (a.i. krezoksimmethil + epoxiconazol + fenpropimorph) $0.75 \mathrm{~L} \mathrm{ha}^{-1}$, at $\mathrm{BBCH} 60$ Fastac 50 EC (a.i. alpha-cypermethrin) $0.25 \mathrm{~L} \mathrm{ha}^{-1}+$ Allegro Super (a.i. krezoksim-methil + epoxiconazol + fenpropimorph) $0.75 \mathrm{~L} \mathrm{ha}^{-1}$. In 2018 at BBCH 23 Arrat (a.i. tritosulfuron + dicamba) $0.2 \mathrm{~kg} \mathrm{ha}^{-1}$, at $\mathrm{BBCH} 53$ Allegro Super (a.i. krezoksim-methil + epoxiconazol + fenpropimorph) $0.75 \mathrm{~L} \mathrm{ha}^{-1}$, at BBCH 69 Allegro Super (a.i. krezoksim-methil + epoxiconazol + fenpropimorph) $0.75 \mathrm{~L} \mathrm{ha}^{-1}$.

The net plot size was $11.5 \times 6.5 \mathrm{~m}=74.75 \mathrm{~m}^{2}$. A randomised complete block design with three replications was used. The treatments were assigned randomly.

Experiment II - different intensity soil tillage impact on agrophytocenosis. The trial was carried out in 2003 in the experimental crop rotation field. The geographical location of the site is lat. $55^{\circ} 72^{\prime} \mathrm{N}$, long. $21^{\circ} 46^{\prime}$ E. The soil was Bathygleyic Dystric Glossic Retisol (WRB, 2014) formed on medium-moraine loam with a texture of sandy loam (clay particles $<0.002 \mathrm{~mm}-$ $13-15 \%$ ), whose $\mathrm{pH}$ at the beginning of the trial was 5.15.3. The soil is moderate in humus status (humus $-2.43 \%$, $\mathrm{C}_{\text {org }}-1.41 \%$ ), moderate in mobile $\mathrm{P}_{2} \mathrm{O}_{5}$ content and high in mobile $\mathrm{K}_{2} \mathrm{O}$ (106 and $270 \mathrm{mg} \mathrm{kg}^{-1}$ soil, respectively) (Skuodienè et al., 2018). Treatments of primary soil tillage: 1) conventional ploughing $(22-5 \mathrm{~cm}), 2)$ shallow ploughing $(12-15 \mathrm{~cm})$ and 3$)$ shallow ploughless tillage $(7-10 \mathrm{~cm})$.

Conventional and shallow ploughing was carried out with ploughs fitted with semi screw 
mouldboards. Conventional and shallow ploughing was performed three weeks after scraping (at the depth of $6-8 \mathrm{~cm})$. In the shallow ploughless tillage treatment as well as in ploughed treatments soil cultivation was done only after scraping. Pre-sowing tillage was the same in all treatments of the primary soil tillage: cultivation with a combined pre-sowing soil tillage cultivator.

The four-course crop rotation consisted of: in 2015 - red clover (T. pratense L.) cultivar 'Sadūnai' of the first year of use, in 2016 - winter wheat (Triticum aestivum L.) cultivar 'Ada', in 2017 - spring rape (B. napus L. ssp. oleifera annua Metzg) cultivar 'Acheras', in 2018- spring barley (H. vulgare L.) cultivar 'Luokè' with undersown red clover. Crops were fertilised with mineral fertilisers. The rate for the stand of barley was $\mathrm{N}_{60} \mathrm{P}_{60} \mathrm{~K}_{0}$, for the perennial grasses $\mathrm{P}_{90} \mathrm{~K}_{90}$, for the winter wheat $-\mathrm{N}_{90} \mathrm{P}_{60} \mathrm{~K}_{90}$, for the spring rape $-\mathrm{N}_{150} \mathrm{P}_{90} \mathrm{~K}_{150}$. Before sowing, the grains of winter wheat and spring barley were treated with Kinto (a.i. triticonazole + prochloraze) at a rate of $2 \mathrm{~L} \mathrm{t}^{-1}$.

Plant protection products (pesticides) were used: in 2016 at BBCH 31 - Fastac 50 EC (a.i. alphacypermethrin) $0.25 \mathrm{~L} \mathrm{ha}^{-1}+$ Allegro Super (a.i. krezoksimmethil + epoxiconazol + fenpropimorph) $0.75 \mathrm{~L} \mathrm{ha}^{-1}$, at BBCH 71 - Fastac 50 EC (a.i. alpha-cypermethrin) $0.2 \mathrm{~L} \mathrm{ha}^{-1}+$ Allegro Super (a.i. krezoksim-methil + epoxiconazol + fenpropimorph) $0.75 \mathrm{~L} \mathrm{ha}^{-1}$; in 2017 at BBCH 01 - Butisan 400 (a.i. metazachlor) $2.5 \mathrm{~L} \mathrm{ha}^{-1}$, at BBCH 12 - Fury (a.i. zeta-cypermethrin) $0.1 \mathrm{~L} \mathrm{ha}^{-1}$, at BBCH 16 - Galera (a.i. clopyralid + picloram) $0.3 \mathrm{~L} \mathrm{ha}^{-1}$, at BBCH 50-60 - Avaunt (a.i. indoxacarb) $0.17 \mathrm{~L} \mathrm{ha}^{-1}$. Due to the prolonged rainy period in the autumn of 2017 , the primary soil tillage was not carried out. Therefore, before the soil tillage in the spring of 2018, Barbarian 2 (a.i. glyphosate) $\mathrm{L} \mathrm{ha}^{-1}$ was applied; in 2018 at BBCH 32, MCPA Super (a.i. MCPA) 1.0 $\mathrm{L} \mathrm{ha}^{-1}$ was used.

Annually, after harvesting of each crop of the rotation and before the primary soil tillage, $400 \mathrm{~kg}$ of $\mathrm{CaCO}_{3}$ was spread to prevent soil acidification. After spreading the straw of winter wheat and rape, a rate of $10 \mathrm{~kg}$ nitrogen $(\mathrm{N})$ was distributed per each ton of straw. The net plot size was $10 \times 5 \mathrm{~m}=50 \mathrm{~m}^{2}$. A randomised complete block design with four replications was used. The treatments were assigned randomly.

Analytical methods. Agrochemical characteristics of the soil were determined on the soil samples taken from $0-20 \mathrm{~cm}$ layer before establishing the experiment: soil $\mathrm{pH}_{\mathrm{KCl}}$ was measured according to potentiometric method determined in $1 \mathrm{M} \mathrm{KCl}$ (soil and solution ratio 1:2.5) (ISO 10390:2005 - Soil quality - Determination of $\mathrm{pH}$ ), mobile $\mathrm{P}_{2} \mathrm{O}_{5}$ and $\mathrm{K}_{2} \mathrm{O}$ - using Egner-Riehm-Domingo (A-L) method (LVP D-07:2016). Mobile Al was determined after Sokolov method according to standards ISO11260 and ISO14254 (Soil quality - Determination of exchangeable acidity using barium chloride solution as extractant). Humus was determined according to Tiurin method (ISO 10694:1995 - Soil quality - Determination of organic and total carbon after dry combustion). Soil bulk density in $0-30 \mathrm{~cm}$ topsoil was determined every $5 \mathrm{~cm}$ using a metal cylinder $\left(100 \mathrm{~cm}^{3}\right)$ by the Kachinsky method. Weeds were handharvested in stationary plots of $0.25 \mathrm{~m}^{2}$ in six spots of each plot. Crop weediness in the stands of winter triticale, winter wheat and spring barley was determined during the periods of tillering and wax maturity before harvesting; in the stands of spring rape - during the periods of shooting and wax maturity before harvesting while in the sward of red clover - before cutting. During the first assessment, weed specific composition was determined, during the second assessment, the weeds were eradicated and their specific composition as well as dry matter mass was determined. Weed number was recalculated to weeds $\mathrm{m}^{-2}$ and mass - dry matter (DM) mass, $\mathrm{g} \mathrm{m}^{-2}$. Weeds were cut at the soil surface and their biomass was weighed by species after the samples had been dried.

Soil contamination with weed seeds was investigated at the depths of $0-10,10-20$ and $20-30 \mathrm{~cm}$. Soil samples were randomly taken from each plot using an agrochemical drill during crop maturity phase. The total number of samples was 360 . The soil was dried out. Then, five samples of dry soil of each of 360 samples (100 g each) were weighed and wet-sieved through a $0.25 \mathrm{~mm}$ sieve until all contents of the soil were washed out. The remaining mineral part of the soil was separated from the organic part and weed seeds using the saturated salt solution. After completion of soil washing, the remaining contents were dried on filter paper. Weed seeds were counted and identified using binoculars with $8.75 \times$ magnification. Weed seed number was recalculated to thousands of weeds $\mathrm{m}^{-2}$ using the following equation:

$\mathrm{A}=\mathrm{n} \times \mathrm{h} \times \mathrm{p} \times 100$,

where $\mathrm{A}$ is weed seed number per $\mathrm{m}^{2}, \mathrm{n}-$ seed number in a sample, $\mathrm{h}$ - soil depth $(\mathrm{cm}), \mathrm{p}$ - soil density $\left(\mathrm{Mg} \mathrm{m}^{-3}\right)$.

Meteorological conditions. In 2015, plant vegetation started on the $14^{\text {th }}$ of April. The amount of precipitation in spring reached $135 \%$, in summer $-90 \%$, in autumn $-79 \%$ of the standard climate norm (SCN). The weather in August was especially warm and dry, the recorded amount of rainfall reached only $12.5 \mathrm{~mm}$ or $13.0 \%$ of the SCN; the mean monthly air temperature was $2.4^{\circ} \mathrm{C}$ higher than the SCN. Plant vegetation period ended on the $26^{\text {th }}$ of November.

In 2016, the period of plant vegetation started on the $8^{\text {th }}$ of April. The amount of precipitation through the year reached $113 \%$ of the SCN. The months of April and May were warm and humid and the average air temperature was by $0.2-2.4^{\circ} \mathrm{C}$ higher than the SCN. The summer was relatively warm and humid: the average air temperature in June reached $16.3^{\circ} \mathrm{C}$ and exceeded the $\mathrm{SCN}$ by $1.8^{\circ} \mathrm{C}$, and in July and August it was close to the SCN. The summer was slightly more humid than the norm - on the average $115 \%$ of the SCN. In September, the weather was warm and dry; however, starting from the second ten-day period of October it became cold, and the plant vegetation period ended on the $16^{\text {th }}$ of October. Soil humidity conditions for agricultural plants to grow were optimal during the whole vegetation period.

In 2017 , the period of plant vegetation started on the $5^{\text {th }}$ of April. Although the amount of precipitation reached $140 \%$ of the $\mathrm{SCN}$, its distribution was uneven: in spring it was by $25 \%$ lower, in summer - by $20 \%$ lower and in the autumn - by $117 \%$ higher than the SCN. The average temperature through the vegetation period was close to the norm and through the year it was $0.5^{\circ} \mathrm{C}$ higher than the SCN. The mean air temperature in November was by $1.8^{\circ} \mathrm{C}$ higher, so the period of vegetation ended only on the $23^{\text {rd }}$ of November.

In 2018 , the period of plant vegetation started on the $13^{\text {th }}$ of April. The amount of precipitation through the year reached $84 \%$ of the SCN. During the vegetation period, the amount of precipitation was by $8 \%$ lower and in the summer time - by $35 \%$ lower compared to the SCN. Soil moisture at the $0-20 \mathrm{~cm}$ depth on the $23^{\text {rd }}$ of July was lower (by 10.26-10.71\%) than the optimal moisture for the plants. Plant vegetation ended on the $24^{\text {th }}$ of November.

Statistical analysis. Significance of the differences between the means was determined according to the Fisher's protected least significant difference (LSD) at 0.05 probability level. The data were processed using analysis of variance (ANOVA) (Raudonius, 2017). Weediness data (weed number and mass) that did not correspond to the law of normal distribution were 
transformed before the statistical evaluation using the equation:

$$
\mathrm{Y}=\sqrt{x+1}
$$

where $\mathrm{x}$ is the primary data, $\mathrm{Y}-$ transformed data of weed density and mass; however, means on the original scales are reported.

\section{Results and discussion}

Management factors change the biodiversity of agroecosystems. Crop rotation, liming and technologies applied are significant for the diversity of weed community (Ciuberkis et al., 2006; Andreasen, Streibig, 2011).

The impact of liming on weed germination. Weeds exhibit a different response to soil acidity, which determines crop nutrition, distribution and yield. Improvement of crop nutrition through liming (reduction of mobile $\mathrm{Al}$, which is harmful to plants) results in the changes in weed number and species composition in a crop (Ciuberkis et al., 2006; Skuodienè, Repšienė, 2009). The influence of liming on crop weediness during the period of shooting or tillering was determined in all experimental years (Table 1).

Table 1. Number of weed seedlings $\mathrm{m}^{-2}$

\begin{tabular}{lccc}
\hline \multirow{2}{*}{ Treatment } & $\begin{array}{c}\text { Spring barley }+ \\
\text { undersowing }\end{array}$ & $\begin{array}{c}\text { Red } \\
\text { clover }\end{array}$ & $\begin{array}{c}\text { Winter } \\
\text { triticale }\end{array}$ \\
\cline { 2 - 4 } & 2016 & 2017 & 2018 \\
\hline Unlimed (pH 4.0-4.1) & 134.0 & 104.0 & 64.0 \\
Limed (pH 6.4-6.8) & $28.7 * *$ & $30.7^{*}$ & $14.7^{*}$ \\
\hline$*$
\end{tabular}

* - significant at $P \leq 0.05, * *$ - at $P \leq 0.01$
A greater competitive ability of crops of the rotation formed in the soil with $\mathrm{pH}$ 6.4-6.8 and led to a total decrease of crop weediness. The weed number per square meter was significantly lower in most of the cases compared to the unlimed soil. In the soil with $\mathrm{pH} 4.0-4.1$, in one square meter of spring barley stand the number of weeds was on average 4.7 times, in red clover 3.4 times and in winter triticale 4.4 times greater than in the soil with pH 6.4-6.8.

Weed number and dry biomass during the period of crop maturity. During the period of crop maturity, weed number per square meter and dry biomass in the soil with $\mathrm{pH}$ 6.4-6.8 were significantly lower in most of the cases compared to the soil with $\mathrm{pH} 4.0-4.1$ (Table 2).

In unlimed soil, in one square meter of spring rape stand the number of weeds was determined to be on average 3.3 times, in the stand of spring barley 4.0 times, in the sward of red clover 3.8 times and in the stand of winter triticale 1.6 times greater than in the soil with $\mathrm{pH}$ 6.4-6.8. A similar trend was found when analysing the weed biomass. In unlimed soil in the stand of spring barley, weed dry biomass was 15 times, in the sward of red clover 2.8 times, and in the stand of winter triticale 3.6 times greater compared to the limed plots.

Weed species diversity in the crops of the rotation during the plant vegetation period. In all crops of the rotation, the lowest weed species diversity was determined in the soil with $\mathrm{pH}$ 6.4-6.8 (Table 3). Irrespective of the soil $\mathrm{pH}$, the greatest number of weed species (8-11 species) was estimated in 2016, when humid and warm weather during the period of vegetation was favourable not only for spring barley but also for weed

Table 2. Number of weeds and dry biomass during the period of crop maturity

\begin{tabular}{|c|c|c|c|c|}
\hline \multirow[t]{2}{*}{ Treatment } & $\begin{array}{l}\text { Spring } \\
\text { rape }\end{array}$ & $\begin{array}{l}\text { Spring barley }+ \\
\text { undersowing }\end{array}$ & $\begin{array}{c}\text { Red } \\
\text { clover }\end{array}$ & $\begin{array}{l}\text { Winter } \\
\text { triticale }\end{array}$ \\
\hline & 2015 & 2016 & 2017 & 2018 \\
\hline \multicolumn{5}{|c|}{ Weeds $\mathrm{m}^{-2}$} \\
\hline Unlimed (pH 4.0-4.1) & 74.0 & 351.0 & 82.0 & 38.0 \\
\hline Limed (pH 6.4-6.8) & $22.7 * *$ & $88.0 *$ & $21.3^{*}$ & 23.3 \\
\hline \multicolumn{5}{|c|}{ Weed dry biomass $\mathrm{g} \mathrm{m}^{-2} \mathrm{DM}$} \\
\hline Unlimed (pH 4.0-4.1) & - & 141.0 & 105.9 & 71.4 \\
\hline Limed (pH 6.4-6.8) & - & $9.4 * *$ & 38.0 & $19.7 *$ \\
\hline
\end{tabular}

DM - dry matter; * - significant at $P \leq 0.05, * *-$ at $P \leq 0.01$

Table 3. Liming impact on weed species number in crops of the rotation, species $\mathrm{m}^{-2}$

\begin{tabular}{|c|c|c|c|}
\hline Crops & $\begin{array}{l}\text { Development period } \\
\text { of plants }\end{array}$ & $\begin{array}{c}\text { Unlimed } \\
\text { (pH 4.0-4.1) }\end{array}$ & $\begin{array}{c}\text { Limed } \\
(\mathrm{pH} \mathrm{6.4-6.8)}\end{array}$ \\
\hline \multirow{2}{*}{ Spring rape, 2015} & shooting & - & - \\
\hline & maturity & 5 & $2 *$ \\
\hline \multirow{2}{*}{ Spring barley + undersowing, 2016} & tillering & 5 & $3 *$ \\
\hline & maturity & 11 & 8 \\
\hline \multirow{2}{*}{ Red clover, 2017} & beginning of flowering, $1^{\text {st }}$ cut & 4 & 4 \\
\hline & beginning of flowering, $2^{\text {nd }} \mathrm{cut}$ & 4 & 3 \\
\hline Winter triticale, 2018 & $\begin{array}{l}\text { tillering } \\
\text { maturity }\end{array}$ & $\begin{array}{l}3 \\
2\end{array}$ & $\begin{array}{l}2 * \\
2\end{array}$ \\
\hline
\end{tabular}

*-significant at $P \leq 0.05, * *$ - at $P \leq 0.01$

growth and development. Irrespective of the soil $\mathrm{pH}$, in normally dense red clover sward (2017) the number of weed species was not high (3-4 species). The lowest weed species diversity was determined in the stand of winter triticale (2018). This was influenced by dry weather in spring and summer; the amount of precipitation reached only $70 \%$ of the standard climate norm.

Liming of acid soils improves not only chemical soil characteristics and ecological plant growth conditions but also reduces crop weediness and changes the abundance of particular weed species (Čiuberkis, 2009). Acidophilic weeds tolerate the shortage of calcium and usually dominate in acid soils (Ciuberkis et al., 2006). In the present research, common spurrey (Spergula arvensis L.), annual knawel (Scleranthus annuus L.) and sheep's sorrel (Rumex acetosella L.) spread more in the soil with $\mathrm{pH} 4.0-4.1$, while fat hen (Chenopodium album L.), wild radish (Raphanus raphanistrum L.) and pale persicaria (Persicaria lapathifolia L.) spread more in limed soil. Other researchers indicate that together with decrease of the soil acidity after liming, the number of acidophilic weeds decreased as well (Ciuberkis et al., 2006), and the total weed number significantly depended on the amount of mobile Al in the soil (Skuodienè, Repšienè, 2009).

The total weed seed quantity through all experimental years was significantly lower in limed soil compared to unlimed soil. According to the mean data, 358.5-433.3 thousand of weed seeds $\mathrm{m}^{-2}$ were found in naturally acid soil seed bank (Table 4), while in the 
Table 4. Contamination of naturally acid and limed soil with weed seeds, thousand seeds $\mathrm{m}^{-2}$

\begin{tabular}{|c|c|c|c|c|}
\hline Treatment & $\begin{array}{c}\begin{array}{c}\text { Spring } \\
\text { rape }\end{array} \\
2015 \\
\end{array}$ & $\begin{array}{c}\begin{array}{c}\text { Spring barley }+ \\
\text { undersowing }\end{array} \\
2016\end{array}$ & $\begin{array}{c}\text { Red } \\
\text { clover }\end{array}$ & $\begin{array}{c}\begin{array}{c}\text { Winter } \\
\text { triticale }\end{array} \\
2018\end{array}$ \\
\hline \multicolumn{5}{|c|}{$0-10 \mathrm{~cm}$} \\
\hline Unlimed (pH 4.0-4.1) & 192.8 & 180.3 & 159.6 & 80.5 \\
\hline Limed (pH 6.4-6.8) & $22.0 * *$ & $7.3 * *$ & $7.4 * *$ & $10.8 * *$ \\
\hline \multicolumn{5}{|c|}{$10-20 \mathrm{~cm}$} \\
\hline Unlimed (pH 4.0-4.1) & 183.9 & 143.6 & 139.6 & 169.7 \\
\hline Limed (pH 6.4-6.8) & $16.2 * *$ & $8.9 * *$ & $10.7 * *$ & $10.9 * *$ \\
\hline \multicolumn{5}{|c|}{$20-30 \mathrm{~cm}$} \\
\hline Unlimed (pH 4.0-4.1) & 56.5 & 57.6 & 59.3 & 116.1 \\
\hline Limed (pH 6.4-6.8) & $6.1 * *$ & $5.0 * *$ & $4.1 * *$ & $5.8 * *$ \\
\hline
\end{tabular}

* - significant at $P \leq 0.05, * *$ - at $P \leq 0.01$

soil with $\mathrm{pH}$ 6.4-6.8 there were 21.2-44.4 thousand of weed seeds $\mathrm{m}^{-2}$ or on average 14.2 times less compared to unlimed soil. Soil liming created favourable conditions for the growth of agricultural plants, therefore they grew faster than in unlimed soil and smothered weeds in the crop rotation. As a result, weed seed production decreased. Irrespective of the soil $\mathrm{pH}$, vertical seed distribution was determined to be similar in different depths of the soil. The greatest number of weed seeds was found at the depths of $0-10$ and $10-20 \mathrm{~cm}$, respectively: $45.6 \%$ and $37.7 \%$ of the total number in unlimed soil and $39.1 \%$ and $41.6 \%$ of the total number in limed soil. The lowest (16.7-19.3\%) seed number was found at a soil depth of 20 $30 \mathrm{~cm}$. Soil contamination with weed seeds depended on crop condition as well as application of agromeasures and corresponds to consistent patterns indicated in literature (Woźniak, Soroka, 2015; Auškalnienè et al., 2018; Skuodienè et al., 2018). The seed bank is an indicator of past and present weed populations.

The influence of primary soil tillage methods on weed germination. An interest in reduced soil tillage in Lithuania has been shown during the last $10-15$ years. It was established that shallow ploughing did not exert any negative effect on soil agrochemical and physical properties, nonetheless, according to research evidence, abandonment of ploughing and using shallow loosening by a rotary cultivator in spring, compared with deep autumn ploughing, resulted in an increase in weed incidence in a barley crop by 2.3-10.3 times (Auškalnienè et al., 2011).

In high productivity Cambisol with $\mathrm{pH}$ 6.9-7.0, significant differences in the weed species composition between the different tillage systems were recorded: no tillage system promoted infestation of some broadleaf weeds, particularly shepherd's purse (Capsella bursapastoris (L.) Med.). The lowest weed mass was determined for the conventional tillage plots compared to minimum tillage, and especially for no tillage plots (Auškalnienè et al., 2018). In low productivity Retisol with $\mathrm{pH}$ 5.1-5.3, primary soil tillage method had significant impact on the weediness of crop rotation in all experimental years. In shallow tillage soil, the number of weeds and dry mass were significantly greater as well as the diversity of weed species compared to conventional ploughing plots. Red clover sward was the least weedy crop (2015) of the rotation: the low weed number was influenced by a good density. However, in shallow ploughing plots of the red clover sward, the weed number was estimated to be significantly greater compared to conventional ploughing plots.

In spring, during the period of tillering in the crops of winter wheat (2016) the weed number was significantly greater (2.4 times) in the plots of shallow ploughless tillage. No significant differences between soil tillage systems were recorded for spring rape crops (2017) (Table 5). In shallow ploughing and shallow ploughless tillage plots, spring barley stand with undersown red clover (2018) was weedier compared to conventional ploughing plots, 2.2 and 1.7 times, respectively. Crop type had the most significant influence on species composition, although it had a low impact on species richness (Fried et al., 2008).

Table 5. Number of weed seedlings $\mathrm{m}^{-2}$

\begin{tabular}{lcccc}
\hline \multirow{1}{*}{\multicolumn{1}{c}{ Soil tillage }} & $\begin{array}{c}\text { Red } \\
\text { clover }\end{array}$ & $\begin{array}{c}\text { Winter } \\
\text { wheat }\end{array}$ & $\begin{array}{c}\text { Spring } \\
\text { rape }\end{array}$ & $\begin{array}{c}\text { Spring barley }+ \\
\text { undersowing }\end{array}$ \\
\cline { 2 - 5 } & 2015 & 2016 & 2017 & 2018 \\
\hline Conventional ploughing & 12.7 & 52.7 & 156.0 & 88.0 \\
Shallow ploughing & $42.7^{*}$ & 83.3 & 164.0 & 193.3 \\
Shallow ploughless tillage & 34.7 & $124.0^{*}$ & 165.3 \\
\hline
\end{tabular}

* - significant at $P \leq 0.05, * *$ - at $P \leq 0.01$

Weed number and dry biomass during the period of cereal and rape maturity. The influence of primary soil tillage on crop weediness remained during the period of crop maturity as well. According to Woźniak (2018), most of the weeds appeared in the second half of the vegetative season and underwent complete development cycle on the stubble field. Before harvesting, in the shallow ploughless tillage soil in the stand of winter wheat (2016), the weed number was by 1.4 times greater and in the plots of shallow ploughing and shallow ploughless tillage in the stand of spring rape (2017) it was by 1.7 and 1.2 times greater compared to the conventional ploughing plots (Table 6). A similar trend was determined in the spring barley stand (2018) as well: in the plots of shallow ploughing the number of weeds was estimated to be significantly or 3.0 times greater and in the plots of shallow ploughless tillage 1.9 times greater compared to conventional ploughing plots.
Different intensity soil cultivation methods had an ambiguous influence on weed dry biomass. In the shallow ploughing plots of spring rape and spring barley, the weed dry biomass was by 1.4 and 2.2 times greater compared to the conventional ploughing plots, and in the shallow ploughless tillage plots of winter wheat a significant difference was determined as well. Woźniak (2018) indicates that more weeds occurred in the winter wheat crop in the reduced tillage and herbicide treatment systems than in the conventional tillage system, although they produced higher biomass in the reduced tillage than in conventional tillage and herbicide treatment systems.

Weed species diversity in the crops of the rotation during plant vegetation period. The research results show that soil tillage methods change the diversity of weed species (Table 7).

In the third crop rotation of previous experimental years, the number of weed species was determined to 
Table 6. Number of weeds and dry biomass during the period of cereal and rape maturity

\begin{tabular}{|c|c|c|c|c|c|c|}
\hline \multirow[b]{2}{*}{ Soil tillage } & \multicolumn{2}{|c|}{$\frac{\text { Winter wheat }}{2016}$} & \multicolumn{2}{|c|}{$\begin{array}{c}\text { Spring rape } \\
2017 \\
\end{array}$} & \multicolumn{2}{|c|}{$\begin{array}{c}\text { Spring barley }+ \text { undersowing } \\
2018\end{array}$} \\
\hline & $\begin{array}{c}\text { weed } \\
\mathrm{m}^{-2}\end{array}$ & $\begin{array}{l}\text { weed dry } \\
\text { biomass } \\
\mathrm{g} \mathrm{m}^{-2} \mathrm{DM}\end{array}$ & $\begin{array}{c}\text { weed } \\
\mathrm{m}^{-2}\end{array}$ & $\begin{array}{l}\text { weed dry } \\
\text { biomass } \\
\mathrm{g} \mathrm{m}^{-2} \mathrm{DM}\end{array}$ & $\begin{array}{c}\text { weed } \\
\mathrm{m}^{-2}\end{array}$ & $\begin{array}{l}\text { weed dry } \\
\text { biomass } \\
\mathrm{g} \mathrm{m}^{-2} \mathrm{DM}\end{array}$ \\
\hline Conventional ploughing & 62.7 & 11.1 & 156.0 & 130.6 & 88.0 & 40.6 \\
\hline Shallow ploughing & 72.7 & 21.5 & 268.0 & 188.4 & $260.0 *$ & 87.4 \\
\hline Shallow ploughless tillage & 87.3 & $61.9 *$ & 185.3 & 125.2 & 169.3 & 51.1 \\
\hline
\end{tabular}

DM - dry matter; * - significant at $P \leq 0.05, * *$ - at $P \leq 0.01$

Table 7. Primary soil tillage impact on weed species number in crops of the rotation, species $\mathrm{m}^{-2}$

\begin{tabular}{|c|c|c|c|c|}
\hline Crops & $\begin{array}{l}\text { Development period } \\
\text { of plants }\end{array}$ & $\begin{array}{l}\text { Conventional } \\
\text { ploughing }\end{array}$ & $\begin{array}{c}\text { Shallow } \\
\text { ploughing }\end{array}$ & $\begin{array}{c}\text { Shallow } \\
\text { ploughless tillage }\end{array}$ \\
\hline Red clover, 2015 & flowering & 2 & 5 & 4 \\
\hline Winter wheat, 2016 & $\begin{array}{l}\text { tillering } \\
\text { maturity }\end{array}$ & $\begin{array}{l}4 \\
6 \\
\end{array}$ & $\begin{array}{l}5 \\
5\end{array}$ & $\begin{array}{c}7 * \\
5\end{array}$ \\
\hline Spring rape, 2017 & $\begin{array}{l}\text { shooting } \\
\text { maturity }\end{array}$ & $\begin{array}{l}7 \\
5 \\
\end{array}$ & $\begin{array}{l}8 \\
7 \\
\end{array}$ & $\begin{array}{l}11 * \\
11 * *\end{array}$ \\
\hline Spring barley + undersowing, 2018 & $\begin{array}{l}\text { tillering } \\
\text { maturity }\end{array}$ & $\begin{array}{l}3 \\
6 \\
\end{array}$ & $\begin{array}{r}4 \\
3 * \\
\end{array}$ & $\begin{array}{c}8^{*} \\
5 \\
\end{array}$ \\
\hline
\end{tabular}

* - significant at $P \leq 0.05, * *$ - at $P \leq 0.01$

be 6-9 during the period of tillering and 3-6 during the period of maturity under the intensive soil tillage system, while in the plots of reduced tillage the number of weed species was by $13-44 \%$ greater (Skuodienè et al., 2016). Shallow ploughless tillage stimulated biological diversity of weeds. Applying conventional ploughing during the period of crop tillering of all experimental years, the number of weed species was found to be significantly lower compared to the shallow ploughless tillage plots. In the plots of shallow ploughing and shallow ploughless tillage, the number of weed species was found to be greater than in the conventional soil tillage plots, respectively: $1.1-1.3$ and 1.6-2.7 times. Other researchers indicate that the number of weed species increases together with decrease of the soil tillage intensity (Hyvönen, Salonen, 2002; Edesi et al., 2012; Kolárová et al., 2013). Under direct drilling, most weed species were found to exhibit higher constancy compared to plough tillage plots (Gawęda et al., 2015).

Irrespective of the soil tillage methods, corn mayweed (Tripleurospermum perforatum (Merat.) M. Lainz), annual meadow grass (Poa annua L.) and common knotweed (Polygonum aviculare L.) were found in all plots of the red clover sward (2015). However, the greatest amount of these weeds was determined in the shallow ploughing plots. During the period of tillering, $C h$. album and $P$. aviculare were spread in all plots of the winter wheat stand (2016). P. annua was spread only in the shallow ploughing and shallow ploughles tillage plots. Ch. album and C. bursa-pastoris dominated in all plots of spring rape stand (2017). S. arvensis dominated only in the shallow ploughing and slhallow ploughless tillage plots, while Ch. album was the dominant weed species in all plots of the spring barley stand (2018) as well. In the later vegetation period, i.e. during the period of plant maturity, the impact of soil tillage methods on weed species diversity was not determined. $P$. annua and $P$. aviculare dominated in the stand of winter wheat (2016), and Ch. album dominated in the stands of spring rape (2017) and spring barley (2018).

The weed seed bank is the main source of weeds in agricultural fields. Soil weed seed banks are reserves of viable seeds present on the surface and in the soil. The seed bank consists of new seeds recently shed by a weed plant as well as older seeds that have persisted in the soil for several years. Roger-Estrade et al. (2006) indicate that the depth and inversion tillage appear to be of major importance for weed biomass destruction and seed movement into the soil profile. Soil contamination with weed seeds depended on primary soil tillage method (Table 8). Applying shallow ploughing and shallow ploughless tillage, total weed seeds in the soil was estimated to be 1.7 and 1.5 times greater compared to conventional tillage plots (Table 8).

Table 8. Soil contamination with weed seeds in the soil of different tillage systems, thousand seeds $\mathrm{m}^{-2}$

\begin{tabular}{|c|c|c|c|c|}
\hline Soil tillage & $\begin{array}{l}\text { Red } \\
\text { clover }\end{array}$ & $\begin{array}{l}\text { Winter } \\
\text { wheat }\end{array}$ & $\begin{array}{l}\text { Spring } \\
\text { rape }\end{array}$ & $\begin{array}{l}\text { Spring barley }+ \\
\text { undersowing }\end{array}$ \\
\hline & 2015 & 2016 & 2017 & 2018 \\
\hline \multicolumn{5}{|c|}{$0-10 \mathrm{~cm}$} \\
\hline Conventional ploughing & 26.7 & 18.2 & 10.7 & 8.5 \\
\hline Shallow ploughing & $34.2 * *$ & 23.5 & $26.2 * *$ & $39.0 * *$ \\
\hline Shallow ploughless tillage & $49.3 * *$ & 26.6 & $34.8 * *$ & $53.8 * *$ \\
\hline \multicolumn{5}{|c|}{$10-20 \mathrm{~cm}$} \\
\hline Conventional ploughing & 14.4 & 12.1 & 7.1 & 13.1 \\
\hline Shallow ploughing & 18.1 & 9.4 & 9.4 & $26.4 * *$ \\
\hline Shallow ploughless tillage & $13.1 * *$ & 10.2 & 7.2 & 15.1 \\
\hline \multicolumn{5}{|c|}{$20-30 \mathrm{~cm}$} \\
\hline Conventional ploughing & 10.6 & 3.9 & 6.9 & 10.2 \\
\hline Shallow ploughing & $5.4^{*}$ & 3.5 & 4.8 & $4.1 *$ \\
\hline Shallow ploughless tillage & $4.6 * *$ & 4.1 & 4.0 & $2.9^{* *}$ \\
\hline
\end{tabular}

* - significant at $P \leq 0.05, * *$ - at $P \leq 0.01$

When applying conventional ploughing, the number of weed seeds in the soil seed bank $(0-30 \mathrm{~cm}$ layer $)$ ranged from 24.7 to 51.6 thousand $\mathrm{m}^{-2}$, when applying shallow ploughing the number ranged from 36.4 to 69.6 thousand $\mathrm{m}^{-2}$, and under the shallow ploughless tillage the weed seed number ranged from 40.8 to 71.7 thousand $\mathrm{m}^{-2}$.

Soil tillage methods had a significant influence on vertical weed seed distribution in the soil. When evaluating particular arable soil layer's contamination with weeds, it can be seen that shallow ploughless tillage mostly influenced soil contamination in the $0-10 \mathrm{~cm}$ layer $(72.3 \%$ of the total seed number). At the same depth $61.1 \%$ of weed seeds were found after the shallow ploughing application, and $43.7 \%$ of weed seeds of the total seed number were found after the use of annual conventional ploughing. 
The least contaminated with weed seeds was the $20-30 \mathrm{~cm}$ soil layer when applying shallow tillage without ploughing, shallow ploughing and conventional ploughing, respectively: $7.4,9.2$ and $23.0 \%$ of seeds of the total seed number. Literature indicates that seed bank traits clearly adapt to different types of arable farming. Seed longevity is favoured by frequent tillage, while seed mass is favoured by plant competition (Albrecht, Auerswald, 2009). It is possible to detect historical effects of past crops, sown in sequence, on weed seedbanks for up to three years (Bohan et al., 2011). Reduced tillage allows the bulk of the seed produced the previous year to remain in the most superficial layer of soil, leading to its extensive germination and emergence in subsequent years (Gruber, Claupein, 2009).

\section{Conclusions}

The sustainable use of acid moraine loam Retisol prevailing in Western Lithuania is related to appropriate intensity of liming and tillage.

1. In limed soil ( $\mathrm{pH} 6.4-6.8)$, the total number of weeds was 4.1 times lower compared to naturally acid soil ( $\mathrm{pH}$ 4.0-4.1). Acidophilic weeds, Spergula arvensis and Scleranthus annuus, dominated in the naturally acid soil during the maturity period of agricultural plants through all experimental years. The long-term liming had an impact on the disappearance of dominating acidophilic weeds from the crop communities.

2. In the soil with $\mathrm{pH}$ 6.4-6.8 there were 14.2 times less weed seeds compared to unlimed soil. Irrespective of the soil $\mathrm{pH}$, vertical seed distribution was determined to be similar in different depths of the soil.

3 . In the soil of low acidity (5.1-5.3), with the application of reduced soil tillage throughout the whole plant vegetation period, the total weed number and mass as well as weed diversity were significantly greater compared to conventional ploughing plots. In the early stages of plant development, when plants are especially sensitive to weed competition, the average total weed number in the plots of shallow ploughing and shallow ploughles tillage was 1.6-1.5 times greater compared to conventional ploughing. Weed number and dry matter mass during the period of cereal maturity were 2.0-1.4 and 1.6-1.3 times greater when applying reduced tillage than conventional ploughing.

4. Irrespective of the soil tillage methods, weed species diversity was determined by their ability to grow in particular crops: Tripleurospermum perforatum was found in all plots of the red clover sward, while the consistent components of crop communities: Chenopodium album, Polygonum aviculare and Poa annua were found in all plots of the cereal stand.

5 . In reduced soil tillage treatments, the number of weed seeds was 1.6 times greater than in conventional ploughing plots. Type of tillage strongly influenced vertical seed placement in the soil. Annual application of the shallow ploughless tillage mostly influenced soil contamination with weed seeds $(72.3 \%$ of the total seed number $)$ at the depth of $0-10 \mathrm{~cm}$. At the same depth $61.1 \%$ of weed seeds were found after the use of shallow ploughing, and $43.7 \%$ of weed seeds of the total seed number were found after the use of conventional ploughing.

\section{Acknowledgements}

The chapter presents research findings, obtained through the long-term research programme "Productivity and sustainability of agricultural and forest soils" implemented by Lithuanian Research Centre for Agriculture and Forestry. Also the chapter presents research findings, obtained through the Project "The effect of long-term management of resources of varying intensity on the soils of different genesis and other components of agro-ecosystems" (SIT-9/2015) funded by the Research Council of Lithuania.

Received 21052019

Accepted 28102019

\section{References}

1. Albrecht H., Auerswald K. 2009. Seed traits in arable weed seed banks and their relationship to land-use changes. Basic and Applied Ecology, 10: 516-524. https://doi.org/10.1016/j.baae.2009.02.002

2. Andreasen C., Streibig J. C. 2011. Evaluation of changes in weed flora in arable fields of Nordic countries - based on Danish long - term surveys. Weed Research, 51 (3): 214-226. https://doi.org/10.1111/j.1365-3180.2010.00836.x

3. Auškalnienė O., Pšibišauskienè G., Auškalnis A., Lazauskas S. Povilaitis V., Sakalauskienè S., Sakalauskaitè J., Duchovskis P., Raudonius S. 2011. Changes of segetal flora in Lithuania over the last decades. Trends of Rural Development in the Knowledge Society, 2: 217-222.

4. Auškalnienè O., Kadžienè G., Janušauskaitè D., Supronienè S. 2018. Changes in weed seed bank and flora as affected by soil tillage systems. ZemdirbysteAgriculture, 105 (3): 221-226.

https://doi.org/10.13080/z-a.2018.105.028

5. Berner A., Hildermann I., Fliessbach A., Pfiffer L., Niggli U. Mäder P. 2008. Crop yield and soil fertility response to reduced tillage under organic management. Soil and Tillage Research, 101 (1-2): 89-96. https://doi.org/10.1016/j.still.2008.07.012

6. Bohan D. A., Powers S. J., Champion G., Haughton A. J. Hawes C., Squire G., Cussans J., Mertens S. K. 2011. Modelling rotations: can crop sequences explain arable weed seedbank abundance? Weed Research, 51 (4): 422-432. https://doi.org/10.1111/j.1365-3180.2011.00860.x

7. Ciuberkis S., Bernotas S., Raudonius S. 2006. Long-term manuring on weed flora in acid and limed soils. Acta Agriculturae Scandinavica, Section B: Soil and Plant Science, 56: 96-100. https://doi.org/10.1080/0906471051003104

8. Čiuberkis S. 2009. Effect of soil pH and nutrient content on weed infestation on spring barley crop. Vagos, 84 (37): $12-16$ (in Lithuanian).

9. Deveikytė I., Feiza V., Feizienè D. 2006. Response of weed flora in barley, wheat and rape crops under reduced springtime tillage. Zemdirbyste-Agriculture, 93 (4): 47-54.

10. Edesi L., Järvan M., Adamson A., Lauringson E., Kuht J. 2012. Weed species diversity and community composition in conventional and organic farming: a five-year experiment. Zemdirbyste-Agriculture, 99 (4): 339-346.

11. European Union. 2000. Special Report No. 14/2000 on Greening the Community Agricultural Policy together with the Commissions replies. Official Journal C353/2000, 30 August 2001, p. 0001-0056. http://eur-lex.europa.eu/LexUriServ/ LexUriServ.do?uri=CELEX:32000Y1208(01):EN:HTML

12. Fried G., Norton L. R., Reboud X. 2008. Environmental and management factors determining weed species composition and diversity in France. Agriculture, Ecosystems and Environment, 128 (1-2): 68-76. https://doi.org/10.1016/j.agee.2008.05.003

13. Gaba S., Fried G., Kazakou E., Chauvel B., Navas M. L. 2014. Agroecological weed control using a functional approach: a review of cropping systems diversity. Agronomy for Sustainable Development, 34 (1): 103-119. https://doi.org/10.1007/s13593-013-0166-5

14. Gaweda D., Cierpiała R., Harasim E., Wesołowski M., Bujak K. 2015. Weed infestation of soybean (Glycine max L. Merr.) under different tillage systems. Acta Agrobotanica, 68 (1): 53-58. https://doi.org/10.5586/aa.2015.005

15. Gruber S., Claupein W. 2009. Effect of tillage intensity on weed infestation in organic farming. Soil and Tillage Research, 105 (1): 104-111. https://doi.org/10.1016/j.still.2009.06.001

16. Guinjuan J. R., Garcia A. L., Cantero-Martinez C., Torra J. 2016. Long-term effect of different tillage systems on the emergence and demography of Bromus diandrus in rainfed cereal fields. Weed Research, 56 (1): 31-40. https://doi.org/10.1111/wre.12185

17. Hosseini P., Karimi H., Babaei S., Mashhadi H. R., Oveisi M. 2014. Weed seed bank as affected by crop rotation and disturbance. Crop Protection, 64 (1): 1-6. https://doi.org/10.1016/j.cropro.2014.05.022

18. Hyvönen T., Salonen J. 2002. Weed species diversity and community composition in cropping practices at two intensity levels - a six-year experiment. Plant Ecology, 159 (1): 73-81. https://doi.org/10.1023/A:1015580722191 
19. Karcauskiene D., Cuberkis S., Raudonius S. 2016. Changes of weed infestation under long-term effect of different soil $\mathrm{pH}$ levels and amount of phosphorus:potassium. Acta Agriculturae Scandinavica, Section B: Soil and Plant Science, 66 (8): 688-697 https://doi.org/10.1080/09064710.2016.1203985

20. Khan A. R., Chandra D., Quraishi S., Sinha R. K. 2000. Soil aeration under different soil surface conditions. Journal of Agronomy and Crop Science, 185 (2): 105-112. https://doi.org/10.1046/j.1439-037X.2000.00417.x

21. Kolárová M., Tyšer L., Soukup J. 2013. Diversity of current weed vegetation on arable land in selected areas of the Czech Republic. Plant, Soil and Environment, 59 (5): 208-213. https://doi.org/10.17221/783/2012-PSE

22. Kryzevicius Z., Karcauskiene D., Álvarez-Rodríguez E., Zukauskaite A., Slepetiene E., Volungevicius J. 2019. The effect of over 50 years of liming on soil aluminium forms in a Retisol. The Journal of Agricultural Science, 1-8. https://doi.org/10.1017/S0021859619000194

23. Meyer-Aurich A., Weersink A., Janovicek K., Deen B. 2006. Cost efficient rotation and tillage options to sequester carbon and mitigate GHG emissions from agriculture in eastern Canada. Agriculture, Ecosystems and Environment, 117 (2-3): 119-127. https://doi.org/10.1016/j.agee.2006.03.023

24. Oerke E. C. 2006. Crop losses to pests. Journal of Agricultural Science, 144: 31-43. https://doi.org/10.1017/S0021859605005708

25. Raudonius S. 2017. Application of statistics in plant and crop research: important issues. Zemdirbyste-Agriculture, 104 (4): 377-382. https://doi.org/10.13080/z-a.2017.104.048

26. Repsiene R., Karcauskiene D. 2016. Changes in the chemical properties of acid soil and aggregate stability in the whole profile under longterm management history. Acta Agriculturae Scandinavica, Section B: Soil and Plant Science, 66 (8): 671-676. https://doi.org/10.1080/09064710.2016.1200130

27. Riemens M. M., van der Weide R. Y., Bleeker P. O. Lotz L. A. P. 2007. Effect of stale seedbed preparations and subsequent weed control in lettuce (cv. Iceboll) on weed densities. Weed Research, 47: 149-156.

https://doi.org/10.1111/j.1365-3180.2007.00554.x
28. Roger-Estrade J., Richard G., Bertrand M., Darboux F., Défossez P. 2006. La composante physique. Dore T. et al. (eds). L'agronomie aujourd'hui. ProdInra, p. 225-243 (in French).

29. Seehusen T., Hofgaard I. S., Tørresen K. S., Riley H. 2017. Residue cover, soil structure, weed infestation and spring cereal yields as affected by tillage and straw management on three soils in Norway. Acta Agriculturae Scandinavica, Section B: Soil and Plant Science, 67 (2): 93-109. https://doi.org/10.1080/09064710.2016.1221987

30. Skuodienè R., Repšienè R. 2009. The effects of organic fertilisers and liming on segetal flora in a sustainable crop rotation on acid soil. Zemdirbyste-Agriculture, 96 (4): 154-169.

31. Skuodienė R., Karčauskienè D., Repšienè R. 2016. The influence of primary soil tillage, deep loosening and organic fertilizers on weed incidence in crops. ZemdirbysteAgriculture, 103 (2): 135-142. https://doi.org/10.13080/z-a.2016.103.018

32. Skuodienè R., Karčauskienè D., Repšienė R., Šiaudinis G. 2018. Changes in the weed communities as affected by different primary soil tillage and deep loosening. Acta Agriculturae Scandinavica, Section B: Soil and Plant Science, 68 (7): 643-48. https://doi.org/10.1080/09064710.2018.1455219

33. Volungevicius J., Amaleviciute K., Feiziene D., Feiza V., Slepetiene A., Liaudanskienė I., Versuliene A., Vaisvalavicius R. 2018. The effects of agrogenic transformation on soil profile morphology, organic carbon and physicochemical properties in Retisols of Western Lithuania. Archives of Agronomy and Soil Science, 64 (13): 1910-1923. https://doi.org/10.1080/03650340.2018.1467006

34. Woźniak A. 2007. Content of weed seed in rendzina soil under spring triticale. Annales Universitatis Mariae CurieSkłodowska, Sectio E, Agricultura, 62 (2): 250-256 (in Polish).

35. Woźniak A. 2018. Effect of tillage system on the structure of weed infestation of winter wheat. Spanish Journal of Agricultural Research, 16 (4): e1009. https://doi.org/10.5424/sjar/2018164-12531

36. Woźniak A., Soroka M. 2015. Biodiversity of weeds in pea cultivated in various tillage system. Romanian Agricultural Research, 32: 231-237.

37. WRB. 2014. World reference base for soil resources. World Soil Resources Reports No. 106. FAO, p. 187-189.

ISSN 1392-3196 / e-ISSN 2335-8947

Zemdirbyste-Agriculture, vol. 107, No. 1 (2020), p. 25-32

DOI 10.13080/z-a.2020.107.004

\title{
Piktžolėtumo kitimas taikant ilgalaikị kalkinimą ir supaprastintą žemės dirbimą
}

\author{
R. Skuodienè $\dot{1}^{1}$ D. Karčauskienè ${ }^{1}$, V. Feiza ${ }^{2}$, D. Feizienè ${ }^{2}$, R. Repšienè $\dot{1}^{1}$ G. Šiaudinis ${ }^{1}$ \\ ${ }^{1}$ Lietuvos agrarinių ir miškų mokslų centro Véžaičių filialas \\ ${ }^{2}$ Lietuvos agrarinių ir miškų mokslų centro Žemdirbystès institutas
}

\section{Santrauka}

Daugelis dirvožemio gerinimo priemoniu yra tiesiogiai susijusios su pasèliu piktžolètumo mažinimu. Vakaru Lietuvoje vyraujančio rūgštaus moreninio priemolio nepasotintojo balkšvažemio tvarus naudojimas siejamas su tinkamo intensyvumo kalkinimu ir žemès dirbimu. Tyrimai atlikti 2015-2018 m. Lietuvos agrarinių ir mišku mokslų centro Véžaičių filialo dviejuose ilgalaikiuose eksperimentuose: kalkinimo (įrengto 1949 m.) ir žemės dirbimo (įrengto $2003 \mathrm{~m}$.). Tyrimo tikslas - nustatyti sejjomainos pasėlių piktžolètumo kitimo tendencijas po ilgalaikio skirtingo intensyvumo agronominių priemonių (žemès dirbimo ir kalkinimo) taikymo. Žemės dirbimo variantai: gilus arimas $(22-25 \mathrm{~cm})$, seklus arimas $(12-15 \mathrm{~cm})$, seklus bearimis dirbimas $(7-10 \mathrm{~cm})$; kalkinimo variantai: nekalkinta $\left(\mathrm{pH}_{\mathrm{KCl}} 4,0-4,1\right)$, kalkinta $\left(\mathrm{pH}_{\mathrm{KCl}} 6,2-6,8\right)$. Tirti piktžolètumo rodikliai: bendras piktžolių skaičius ir masè, piktžolių rūšiu skaičius, sẻklų bankas dirvožemio 0-10, 10-20 ir 20-30 cm sluoksniuose.

Tyrimo rezultatai parodè, kad ilgalaikis kalkinimas turèjo ịtakos vyraujančių acidofilinių piktžolių išnykimui pasèliu bendrijose. Bendras piktžoliu skaičius kalkintame dirvožemyje (pH 6,4-6,8) buvo 4,1 karto mažesnis, palyginus su natūraliai rūgščiu dirvožemiu ( $\mathrm{pH} 4,0-4,1)$. Nors dirvožemio užterštumas piktžolių sẻklomis buvo 14,2 karto didesnis natūraliai rūgščiame dirvožemyje, tačiau, nepriklausomai nuo dirvožemio rūgštumo $(\mathrm{pH})$, jų pasiskirstymas vertikaliai dirvožemio sluoksniuose buvo panašus. Pasėlių piktžolètumą mažo rūgštumo (pH $5,1-5,3$ ) dirvožemiuose mažino ilgalaikis gilus arimas. Bendras piktžolių skaičius ir ju masè buvo 1,6 ir 1,4 karto didesni sekliai dirbtame dirvožemyje. Ilgalaikis žemės dirbimas turejo ịtakos dirvožemio supurenimo gyliui, lemiančiam vertikalų piktžolių sẻklų pasiskirstymą. Dirbant sekliai, piktžolių sėklomis labiausiai užterštas buvo dirvožemio $0-10 \mathrm{~cm}$ sluoksnis.

Reikšminiai žodžiai: kalkinimas, piktžolių skaičius ir masė, rudeninis žemės dirbimas, rūgštūs dirvožemiai, sėklų bankas. 